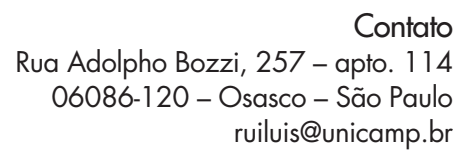

Contato

Rua Adolpho Bozzi, 257 - apto. 114 06086-120 - Osasco - São Paulo ruiluis@unicamp.br

\section{CIDADE SITIADA: O CERCO MILITAR NO SÉCULO XVI COMO ESPAÇO DE UTOPIA E DE CONTRA-UTOPIA - OS EXEMPLOS DE MÜNSTER (1534-1535) E DE SANCERRE (1573)}

\author{
Rui Luis Rodrigues* \\ Universidade Estadual de Campinas \\ Campinas - São Paulo - Brasil
}

\title{
Resumo
}

O objetivo deste trabalho é investigar as formas pelas quais o cerco militar foi representado no século XVI como espaço de utopia e de contra-utopia. O ponto comum entre os dois cercos analisados está no fato de que ambos foram movidos contra populações religiosamente minoritárias assinaladas por configurações de teor utópico-apocalíptico. Ambos os relatos nos permitem vislumbrar a cidade europeia do Quinhentos como espaço privilegiado para construções utópicas, ao mesmo tempo em que se destacam as mecânicas de rejeição da utopia e de criminalização das tentativas de transformação dos ordenamentos sociais. A investigação pressupõe uma preocupação com o tema da memória histórica e de como sua construção pode se converter em discursos ideologicamente condicionados.

\section{Palavras-chave}

Utopia e contra-utopia - Anabatistas em Münster - Huguenotes em Sancerre

* Doutor em História Social pela Faculdade de Filosofia, Letras e Ciências Humanas da Universidade de São Paulo e Professor de História Moderna no Departamento de História do Instituto de Filosofia e Ciências Humanas (IFCH) da Universidade Estadual de Campinas (UNICAMP). 


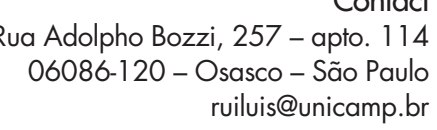

\section{THE CITY BESIEGED:}

THE MILTARY SIEGE IN

SIXTEENTH-CENTURY

AS A PLACE OF UTOPIA

AND COUNTER-UTOPIA

- THE EXAMPLES OF

MÜNSTER (1534-1535)

AND SANCERRE (1573)

\author{
Rui Luis Rodrigues \\ Universidade Estadual de Campinas \\ Campinas - São Paulo - Brasil
}

\begin{abstract}
The aim of this study is to investigate the ways in which military siege was represented in sixteenth century as space of utopia and counter-utopia. The common point between the two sieges analyzed is the fact that both were moved against religiously minority populations with utopian and apocalyptic content settings. Both reports allow us to glimpse the sixteenth-century European city as a privileged space for utopian constructions, while the mechanics of rejection of utopia and criminalization of changes in social ordering are underlined. The research presupposes a preoccupation with the subject of historical memory and how their construction can produce ideologically conditioned speeches.
\end{abstract}

\title{
Keywords
}

Utopia and Counter-Utopia - Anabaptists in Münster - Huguenots in Sancerre 


\section{Conceituações}

Este artigo pretende refletir sobre os espaços urbanos como lugares preferenciais, nos inícios da modernidade, para a produção e difusão de ideários utópicos, e sobre o cerco militar como ocasião especial não apenas para a fermentação desses ideários, mas também para a elaboração da propaganda contra-utópica. Não se desconhece o fato de que o cerco militar ganhou no século XVI uma importância especial por refletir a necessidade, própria dos processos de centralização política, de sufocar as possibilidades de resistência baseadas nas formas municipais de governo. Para tanto, era imprescindível homogeneizar vontades e estruturas de pensamento debaixo da soberania principesca. ${ }^{1}$ Esta é, grosso modo, a moldura que circunda ambas as narrativas de que nos ocuparemos. Nosso exame incidirá sobre dois relatos de sítios militares conduzidos no século XVI: o cerco mantido por tropas católicas e luteranas, entre 28 de fevereiro de 1534 e 25 de junho de 1535, contra a cidade de Münster, agitada pela pregação alcunhada "anabatista" e pela presença de muitos refugiados que professavam essa fé, e narrado por Hermann von Kerssenbrock em sua obra Anabaptistici furoris monasterium inclitam Westphaliae metropolim evertentis historica narratio ${ }^{2}$; e o cerco a que a cidade de Sancerre

\footnotetext{
1 Os debates historiográficos sobre a "centralização monárquica" e a formação dos "absolutismos" são amplamente conhecidos e produziram alguns clássicos da historiografia ao longo do século XX. Todavia, pesquisas recentes têm indicado leituras alternativas importantes, que sublinham as dificuldades enfrentadas por esses processos ao lidarem com a realidade de corpos sociais dotados de direitos e privilégios, os quais se mostravam pouco inclinados a ceder às eventuais pressões dos poderes centrais. Essas pesquisas são largamente tributárias do trabalho seminal de Otto Brunner, em especial BRUNNER, Otto. Land and lordship: structures of governance in medieval Austria. Philadelphia: University of Pennsylvania Press, 1992 (o original alemão é de 1939); mas também das investigações de Gerhard Oestreich (ver em especial OESTREICH, Gerhard. Problemas estruturais do absolutismo europeu. In: HESPANHA, António Manuel (org.). Poder e Instituições na Europa do Antigo Regime: Colectânea de Textos. Lisboa: Fundação Calouste Gulbenkian, 1984, p. 179-200). Ver HESPANHA, António Manuel. As vésperas do Leviathan. Instituições e poder político. Portugal - Século XVII. Coimbra: Almedina, 1994, p. 22-30; Idem. Para uma teoria da história institucional do Antigo Regime. In: Idem. Poder e Instituições na Europa do Antigo Regime: Colectânea de Textos. Lisboa: Fundação Calouste Gulbenkian, 1984, p. 7-89.

2 "Narrativa histórica sobre a loucura dos anabatistas e sobre a subversão de Münster, a ilustre metrópole da Vestfália". Edição crítica do texto em DETMER, Heinrich (ed.). Hermanni a Kerssenbroch, Anabaptistici Furoris Monasterium Inclitam Westphaliae Metropolim Evertentis Historica Narratio. Münster: Druck und Verlag der Theissing'schen Buchhandlung, 1899-1900. 2 v. Todas as citações da obra de Kerssenbrock neste artigo serão feitas a partir dessa edição, aqui referenciada como DETMER, H. Uma tradução para a língua inglesa foi disponibilizada recentemente. Ver KERSSENBROCK, Hermann von. Narrative of the Anabaptist Madness: The Overthrow of Münster, the Famous Metropolis of Westphalia. Tradução, introdução e notas de Christopher S. Mackay. Leiden/
} 
esteve sujeita por sete meses e meio, entre 9 de janeiro e 19 de agosto de 1573, narrado por Jean de Léry em sua Histoire memorable de la ville de Sancerre. ${ }^{3}$

Tornadas em centros nevrálgicos da vida social nos inícios da época moderna, as cidades não juntavam apenas pessoas, mas igualmente seus medos e esperanças. Já eram, então, locais sumamente complexos: ali era possível viver e, não raramente, mudar de cidade podia significar o início de uma nova etapa na vida, com a tentativa de apagamento dos vestígios da vida anterior; mas ali também, sob determinadas circunstâncias, se morria mais rapidamente. O medo dos cercos e a desconfiança em relação aos recém-chegados, que podiam ser batedores de uma invasão futura ou portadores do juízo de Deus trazendo, a reboque de sua má vida ou de tendências heréticas, o flagelo da peste ou da fome, inspiravam complexos mecanismos de controle do ingresso. ${ }^{4}$ Ao mesmo tempo, o engenho humano trabalhava no sentido de tornar a vida citadina mais confortável; na Itália, mais do que em qualquer outro lugar da Europa, as cidades eram o próprio coração da existência social, pensada significativamente como existência cívica, e o poder se ocupava em patrocinar nelas melhorias e embelezamentos. ${ }^{5}$

Não é fortuito, portanto, que a cidade tenha ocupado o centro das diversas formulações utópicas elaboradas e divulgadas durante a primeira modernidade. Isso se liga, igualmente, a uma permanência de longa duração: o imaginário cristão sempre fez da cidade um símbolo fortíssimo e o próprio porvir escatológico foi pensado em termos de uma cidade, a Nova

\footnotetext{
Boston: Brill, 2007. 2 v. Neste artigo, todas as traduções do latim e do francês são de minha responsabilidade.

3 LÉRY, Jean de. Histoire memorable de la ville de Sancerre, contenant les entreprinses, sieges, approches, bateries, assaux et autres efforts des assiegans le tout fidelement recueilli sur le lieu par Jean de Lery. Genève: s.n., 1574. 253 p. Trabalhei com o exemplar conservado na Seção de Obras Raras da Biblioteca do Instituto de Estudos Brasileiros da Universidade de São Paulo (IEB/USP). Agradeço a atenção dispensada pelo Instituto e, em particular, por seus bibliotecários. Agradecimentos devem ser feitos, também, aos Archives Municipales de Lyon, à Bibliothèque Municipale de Lyon e à Bibliothèque nationale de France, onde foram realizadas consultas adicionais importantes para a ultimação deste texto, e à Fundação de Amparo à Pesquisa do Estado de São Paulo (FAPESP) que, através de uma bolsa de apoio a Projeto Regular de pesquisa (Processo 2014/18183-7), permitiu-me o deslocamento e a permanência nos arquivos franceses.

4 Ver a descrição feita por Montaigne para Augsburgo em MONTAIGNE, Michel de. Journal de voyage en Italie par la Suisse et l'Allemagne en 1580 et 1581 (edição M. Rat). Paris: Garnier, 1955, p. 47-8; DELUMEAU, Jean. História do Medo no Ocidente, 1300-1800. Uma cidade sitiada. São Paulo: Companhia das Letras, 1989, p. 11-2.

5 GARIN, Eugenio. Ciência e vida civil no Renascimento italiano. São Paulo: Editora da Unesp, 1996, especialmente capítulo 2 ("A cidade ideal", p. 57-80); NEVOLA, Fabrizio. Tales of the City: Outsiders' Descriptions of Cities in the Early Modern Period. Edição especial de Città e Storia VII, 1 (2012). Roma: s.n., 2012.
} 
Jerusalém, "a cidade que tem fundamentos, cujo arquiteto e construtor é o próprio Deus". Curioso resgate de um símbolo cuja aparição, no mito bíblico, é singularmente negativa: a primeira cidade é atribuída ao esforço edificador de Caim, assassino do próprio irmão e renegado da face de Deus. Mas talvez esse percurso complexo faça sentido, de fato, à luz de uma perspectiva binária da vida que, ao fracasso humano, opõe o triunfo final de Deus. ${ }^{6}$ Por mais de uma razão, portanto, o convívio utópico acabou imaginado, na primeira modernidade, em termos preponderantemente urbanos.

A pesquisa especializada tem feito, em geral, um uso bastante restrito do termo "utopia", no mais das vezes como um gênero literário que teria recebido suas principais características do texto que lhe deu nome, a Utopia de Thomas Morus. A própria redução a um gênero literário, embora compreensível quando alguns autores se propõem o estudo de determinados textos, limita demais a utilização do conceito; e isso se agrava quando a análise desce a detalhes e argumenta que o enquadramento nessa categoria depende não apenas da existência de um texto, excluindo-se assim formulações não literatizadas, mas também de características mais específicas (que, aliás, variam amplamente de intérprete para intérprete): a necessidade de uma moldura ficcional, a descrição obrigatória de sociedades estáticas, visto que ideais, e a ausência de indicação do caminho pelo qual se poderia chegar da realidade criticada ao modelo defendido. ${ }^{7}$

\footnotetext{
${ }^{6}$ Apocalipse, 21, 1-3; Hebreus 11, 10 (para a citação entre aspas); Gênesis 4, 17; CLARK, Stuart. Pensando com demônios: A ideia de bruxaria no princípio da Europa moderna. São Paulo: Edusp, 2006, p. 192-3 (para o caráter "assimétrico" desse binarismo característico da sociedade cristã medieval e da primeira modernidade).

7 Para o estudo do pensamento utópico, ver RUYER, Raymond. L'Utopie et les utopies. Paris: Presses Universitaires de France, 1950; MANUEL, Frank E. \& MANUEL, Fritzie P. El pensamiento utópico en el mundo occidental. Madrid: Taurus, 1984.3 v.; DAVIS, J. C. Utopia y la Sociedad Ideal: Estudio de la literatura utopica inglesa, 1516-1700. México: Fondo de Cultura Económica, 1985; BACZKO, Bronislaw. Utopia. In: Enciclopédia Einaudi. Lisboa: Imprensa Nacional/Casa da Moeda, 1985, vol. 5 , p. 333-96; FORTUNATI, Vita \& TROUSSON, Raymond (ed.). Dictionary of Literary Utopias. Paris: Honoré Champion, 2000; BERRIEL, Carlos Eduardo Ornelas. Brief notes on Utopia, Dystopia and History. In: VIEIRA, Fátima \& FREITAS, Marinela (ed.). Utopia Matters: Theory, Politics, Literature and the Arts. Porto: Editora UP, 2005, p. 101-5. Só tardiamente tive acesso a MUMFORD, Lewis. The Story of Utopias. New York: Boni and Liveright, 1922 (4 ${ }^{\mathrm{a}}$. reimpressão, 1928). Com amplas referências bibliográficas e uma perspectiva mais aberta sobre o fenômeno utópico, ver FRANCO JR., Hilário. O porco, o homem e Deus: A utopia panteísta da Cocanha. In: Idem. Os três dedos de Adão: Ensaios de mitologia medieval. São Paulo: Edusp, 2010, p. 243-69 (especialmente p. 268-9); Idem. A utopia que não está no fim da viagem: a peregrinação medieval. Morus - Utopia e Renascimento, n. 7, 2010, p. 59-82. Assumo com alegria minha dívida para com o professor Hilário Franco Jr., com quem tive ocasião de discutir, anos atrás, várias das ideias aqui expressas.
} 
Nossa intenção não é polemizar com esse largo campo de estudos cujas investigações têm produzido excelentes resultados. Mas cremos que todas essas tentativas de delimitação conceitual, ao pretenderem extrair de determinados textos as principais caracterizações para o fenômeno, acabam dependentes de uma leitura da "utopia" que deve muito aos hábitos mentais da racionalidade moderna. Assim, o projeto utópico é entendido como aquele que parte do homem e que faz do homem o "mestre de seu destino"; é dotado de credibilidade e verossimilhança, enquanto as concepções do "mundo invertido" possuiriam "inverossimilhança declarada"; não teria qualquer relação com as aspirações de restauração religiosa de um passado mítico, na medida em que tais aspirações se relacionariam "a um mundo dado ao homem e não edificado por ele". ${ }^{8}$ Nessa mesma chave, J. C. Davis rejeita estender a qualificação de "utopia" aos sonhos milenaristas que, embora localizando na terra a solução coletiva dos problemas humanos, fazem com que essa solução dependa não fundamentalmente do esforço do homem, mas da intervenção de um deus ex machina. ${ }^{9}$ Para esse autor seria igualmente inadequada a identificação da Cocanha como utopia, visto que nela a análise da sociedade coetânea, a partir da qual se objetivaria a construção de uma alternativa, é substituída pelas fantasias de plena satisfação. ${ }^{10}$ Ao privilegiarem uma noção de utopia calcada em determinados modelos literários, essas análises perdem de vista a centralidade que o dado religioso possuía no conjunto das sociedades europeias da primeira modernidade. Isso não apenas minimiza a importância de outras construções utópicas como pode, inadvertidamente, conduzir a interpretações equivocadas dos próprios textos que são tidos na conta de "fundadores" do pensamento utópico.

Efetivamente, entre os defensores de um conceito estrito de utopia calcado no trabalho de Morus existe a tendência a se evitar a classificação de episódios como o de Münster, bem como construções imaginárias como a da Cocanha, na categoria de "utópicos", em razão de um apego conceitual ao esforço edificador humano como distintivo das utopias. ${ }^{11}$ Essa prática embu-

8 TROUSSON, Raymond. Utopia e utopismo. Morus - Utopia e Renascimento, n. 2, 2005, p. 123-36, aqui p. 128-30.

9 DAVIS, J. C. op. cit., 1985, p. 41-6.

${ }^{10}$ DAVIS, J. C. op. cit., 1985, p. 31; JASMIN, Marcelo. Utopia: memória, palavra, conceito. In: STARLING, Heloísa Maria Murgel; RODRIGUES, Henrique Estrada; TELLES, Marcela (org.). Utopias agrárias. Belo Horizonte: Editora da UFMG, 2008, p. 25-51, aqui p. 45.

${ }^{11}$ Assim também COHN, Norman. The Pursuit of the Millenium. Revolutionary Millenarians and Mystical Anarchists of the Middle Ages. Revised and Expanded Edition. New York: Oxford University Press, 
te uma racionalização ilustrada que dificilmente faria justiça à sensibilidade religiosa da sociedade europeia, não apenas no medievo, mas também durante boa parte da modernidade. A leitura medieval do mito edênico, com sua convicção de que a vida monástica representava uma recuperação do Jardim perdido, sublinha-nos a necessidade de relativizar essa ênfase na utopia como algo feito apenas pelo homem. A expectativa por uma consumação escatológica na eternidade não eliminava a possibilidade da utopia: nesse sentido, a vida monástica representava, naquele contexto, um exercício fundamentalmente utópico. Não era por acaso que o locus mais interior do mosteiro medieval, o claustro, era ocupado por um jardim com uma fonte, numa referência explícita ao Éden. ${ }^{12}$ Assim como o ingresso no Éden definitivo, a eternidade, dependia de certas posturas adotadas pelo homem, o ingresso nessa antecipação do Éden que era a vida monástica dependia de atitudes e ações muito claras por parte do indivíduo (recusa ao saeculum, abnegação, penitência). Ainda que em termos distintos daqueles que predominarão na modernidade mais tardia, fica evidente que no âmbito do medievo e da primeira modernidade esses anseios não excluíam, de uma forma ou de outra, a participação e a agência humanas. O espaço da utopia, portanto, pode ser determinado: o claustro, Münster, Sancerre; seu tempo, igualmente, pode ser o "agora". Aqui aparecem claramente os limites que uma tipificação exclusivamente literária da "utopia", a partir de certas formas de leitura do texto moreano, acabou impondo ao uso mais amplo do conceito.

Cremos que, quando devidamente qualificado, o termo "utopia" pode ser descolado do sentido mais específico que os estudos literários têm atribuído a ele e pode, assim, servir para caracterizar movimentos e ideários que possuíam com as expressões religiosas um contato mais íntimo do que em geral se tem considerado apropriado às utopias. Para as finalidades deste

1970 (primeira edição, 1961), p. 252-80, recusa ao episódio de Münster a categoria de "utópico" e impõe ao fenômeno o rótulo, bastante problemático, de "milenarismo". Em contrapartida, John Gray insiste que o projeto dos anabatistas de Münster deve ser entendido como uma utopia religiosa (ver GRAY, John. Missa Negra: Religião apocalíptica e o fim das utopias. Rio de Janeiro: Record, 2008, p. 11-59). No tratamento sumário que dispensa a Münster (p. 27-30), Gray depende fundamentalmente de Norman Cohn, inclusive na referência a esse fenômeno como apresentando "todas as características do milenarismo" (GRAY, John. op. cit., p. 29), sem atentar para o fato de que, para Cohn, o caráter milenarista exclui o elemento utópico.

12 Gênesis 2, 8-17; 3, 23-24; João 19, 41-42; 20, 11-18; Apocalipse 22, 1. Ver a propósito BOUGAIN, Michel. Le jardin spirituel de l'âme dévote. Paris: Alain Lotrian, 1528; HUCHARD, Viviane \& BourGaIn, Pascale. Le Jardin Médieval: un musée imaginaire. Cluny, des textes et des images, un pari. Paris: Presses Universitaires de France, 2002. 
artigo, entenderemos "utopia", de forma ampla, como todo ideário que embute, de maneira mais ou menos clara, um projeto de reformulação das estruturas sociais e das condições de vida no presente. O projeto utópico pode variar do mais visionário ao mais estritamente metódico; pode comportar aspirações quase oníricas, como as da Cocanha, bem como aquelas vazadas numa linguagem que aparenta grande factibilidade. Pode encontrar formulação escrita numa moldura ficcional ou em textos de caráter mais reflexivo e abstrato; pode se apresentar fragmentado em séries de panfletos ou veiculado através de pregações; pode, finalmente, sequer ter sido expresso num texto específico, mas encontrar-se implícito nas entrelinhas de determinados sistemas de pensamento, ou mesmo ter sido dado a conhecer através de seus detratores, numa dinâmica que obriga o historiador a invocar todas as suas capacidades para a leitura "a contrapelo". Chamaremos de "utopia", portanto, mais as aspirações fundamentais e as linhas gerais dessas idealizações do que um determinado grupo de características que poderia facilmente ser isolado, mas ao custo de descaracterização arbitrária.

A contra-utopia, por sua vez, pode ser compreendida como o reflexo invertido da utopia, elaborado e divulgado por seus inimigos. Tem a finalidade de evidenciar como mal aquilo que a utopia considera como bem. O exercício utópico possui uma dimensão subversiva, em maior ou menor grau: trata-se, sempre, de questionar elementos presentes no status quo, ainda que esse questionamento não subentenda, para o período que estamos estudando, qualquer referência à ideia de "progresso". Bem ao contrário, será sempre a tópica do retorno, da recuperação, e não a do "progresso", que governará a expressão desses ideários na primeira modernidade. Aqui, de fato, destaca-se um elemento útil para compreendermos a distância entre o fenômeno utópico e outra construção mental importante no medievo e na primeira modernidade, aquela do "mundo invertido". Em suas manifestações mais explícitas, como as festas dos loucos e as inversões carnavalescas, o fenômeno do "mundo invertido" não deixava de representar uma forma de legitimação da ordem vigente no restante do tempo. ${ }^{13}$ Diferentemente desses períodos de exceção

\footnotetext{
${ }^{13}$ Ainda que esse aspecto não esgote, obviamente, a complexidade desses fenômenos. Ver a propósito BAKHTIN, Mikhail. A Cultura Popular na Idade Média e no Renascimento: O contexto de François Rabelais. São Paulo/Brasília: Hucitec/Editora da UnB, 4a edição, 1999 (com ênfase no aspecto subversivo dessas festas); Burke, Peter. Cultura popular na Idade Moderna. Europa, 1500-1800. São Paulo: Companhia das Letras, 2010 (especialmente capítulo 7, p. 243-77), para quem o aspecto de controle social, conquanto importante, não exaure o significado dessas manifestações; DAVIS, Natalie Zemon. Culturas do Povo: Sociedade e Cultura no Início da França Moderna. Rio de Janeiro:
} 
que, de uma forma ou de outra, serviam à ordem, a utopia projeta um mundo às avessas permanente, não mais sujeito a esse caráter temporário legitimador do status quo. ${ }^{14}$ A atividade contra-utópica prestava-se, como é óbvio, a desfazer tais formulações, indicando seu caráter perverso, sedicioso, herético.

Um esclarecimento importante diz respeito ao termo "anabatista", empregado nas fontes do período, mas que é um termo elusivo, na medida em que homogeneíza e recobre uma realidade plural e variegada: aquela das simpatias religiosas que, fermentando desde o século XIV em várias regiões do Império, mas com especial intensidade nos Países Baixos e caracterizadas pela insatisfação com as estruturas religiosas vigentes e pelo anseio por uma religiosidade menos dependente de cânones externos, se identificaram a partir da década de 1520 com as ênfases dos grupos "sacramentários" (assim denominados por negarem qualquer realidade à presença de Cristo na Eucaristia) e levaram tais convicções a extremos. O termo "anabatista", que significa literalmente "rebatizador" e que foi fabricado pelos inimigos desses movimentos, é insatisfatório, mas soluções posteriores, como o uso da designação "reforma radical", o são em igual medida. Esta última alternativa, endossada por George Williams em sua obra magistral e que continua uma referência incontornável, possui o inconveniente de expressar um juízo de valor: "radical" pode significar também aquilo que se situa "junto à raiz" e, nesse sentido, o termo corroboraria a tese desses movimentos de que sua forma de vivência do cristianismo seria "mais pura", visto que mais originária. Não foi por acaso que toda uma historiografia sobre os anabatistas, de viés bastante confessional, apropriou-se do termo. ${ }^{15}$ Manteremos, portanto, o uso tradicional da expressão "anabatista" por conta, inclusive, do peso de sua atestação nas fontes, mas conscientes de todas as suas limitações e das distorções que provoca.

Paz e Terra, 1990, especialmente o ensaio "Razões do desgoverno" (p. 87-106). Natalie Z. Davis crê que essas festas devem ser entendidas de forma mais complexa: não apenas reforçavam as instituições, mas também ajudavam a transformá-las e, sob determinadas circunstâncias, eram veículos efetivos para a crítica social.

${ }^{14}$ FRANCO JR., Hilário. op. cit., 2010, p. 268 (para a utopia da Cocanha como "mundo às avessas permanente").

${ }^{15}$ WILliAMS, George H. La Reforma Radical. México: Fondo de Cultura Económica, 1983 (edição original de 1962); FRIESEN, Abraham. Erasmus, the Anabaptists, and the Great Commission. Grand Rapids: Eerdmans, 1998; CLASEN, C. P. Anabaptism: A Social History, 1525-1618. Ithaca: Cornell University Press, 1972. Para importante coletânea de fontes, ver BAYLOR, Michael G. The Radical Reformation. Cambridge: Cambridge University Press, 1991. 


\section{A utopia situada}

Para os anabatistas que, em inícios de 1534, assumiram o controle da importante cidade de Münster (a maior da Vestfália e sede de seu bispado-principesco), ${ }_{1}^{16}$ era ali, e não em Estrasburgo, como anunciara previamente seu profeta Melchior Hofmann, que os 144 mil eleitos mencionados pelo Apocalipse seriam reunidos e, após sobreviverem a um cerco terrível, veriam o reino sacerdotal dos santos se congregar sob pastores escolhidos e justos. Esse era o teor da profecia de Hofmann, divulgada em 1526 e que deveria se cumprir, segundo ele, dali a sete anos, com a chegada do fim do mundo após o verão de 1533. Com a única modificação do teatro dos acontecimentos, de Estrasburgo para Münster, todo o restante da profecia foi mantido na expectativa ardorosa desses fiéis. ${ }^{17}$

As dimensões do sonho desses visionários (seus adversários diriam "loucura", furor) eram claramente utópicas. Mesmo as pretensões iniciais desses grupos anabatistas, antes das polarizações apocalípticas mais decisivas, já indicavam isso. O questionamento das exterioridades religiosas com base na liberdade cristã, por exemplo, excedia em muito o que seria tolerado pelo status quo religioso, mesmo nos territórios luteranos. Essa interiorização total da verdade escapava à lógica religiosa da época, oferecendo riscos que não deixavam de ser ameaçadores ao próprio ordenamento social, razão pela qual cedo foi combatida não apenas pelos católicos, mas inclusive naquelas

\footnotetext{
${ }^{16}$ Para um resumo útil dos eventos, ver COHN, Norman. op. cit., 1970, p. 252-80. Fontes principais, além de Kerssenbrock, em GRESBECK, H. Summarische Ertzelungk und Bericht der Wiederdope und wat sich binnen der Stat Monster in Westphalen zugetragen im Iair MDXXXV, disponível em CORNELIUS, C. A. (ed.). Berichte der Augenzeugen über das münsterische Wiedertäuferreich, volume II de Geschichtsquellen des Bistums Münster. Münster: Druck und Verlag der Theissing'schen Buchhandlung, 1853, p. 3-214. Como Kerssenbrock, Gresbeck também foi testemunha ocular dos eventos. Além de vários outros documentos, esse volume contém ainda as confissões feitas por Beukelzs em julho de 1535 (p. 369-76) e janeiro de 1536 (p. 398-402), bem como a "Confissão de fé e vida da comunidade de Cristo em Münster" (Bekenntnis des Glaubens und Leben der Gemeinde Christi zu Münster), p. 445-64. Escritos dos principais líderes da rebelião, como Beukelzs e Bernardo Rothmann, encontram-se em DETMER, H. Bilder aus den religiösen und sozialen Unruhen in Münster. Münster: Westfalen, 1903-4. 3 v., que não pude consultar. Como era de se esperar, a bibliografia secundária sobre Münster é caudalosa, mas significativamente pouco atualizada; para detalhamentos, ver COHN, Norman. op. cit., 1970, p. 366-9; MACKAY, Christopher S. General Introduction. In: KERSSENBROCK, Hermann von. op. cit., 2007, vol. I, p. 1-77, aqui p. 65-6.

${ }^{17}$ HOFMANN, Melchior. Das XII Capitel des propheten Danielis ausgelegt. In: KROHN, Barthold. Geschichte der fanatischen und enthusiastischen Wiedertäufer vornehmlich in Niederdeutschland: Melchior Hofmann und die Secte der Hofmannianer. Leipzig: Bernhard Christoph Breitkopf, 1758, p. 84-99, especialmente p. 92-6.
} 
regiões do Império germânico onde a reforma luterana se instalou sob os auspícios dos poderes e das magistraturas locais. $\mathrm{O}$ anseio religioso por liberdade e interioridade, ao se expressar, não apenas delimitava uma forma de vivência cristã que se considerava melhor e mais pura, como criticava radicalmente a realidade existente. ${ }^{18}$

O componente apocalíptico pode ser entendido como o cimento que dava liga ao projeto utópico dos anabatistas radicados em Münster. Como documentam não apenas os escritos de seus adversários, mas também os textos sobreviventes de Hofmann e de outros anabatistas ligados ao episódio de Münster, para esses visionários a mediação humana era fundamental para provocar os eventos apocalípticos e instalá-los. Assim, não há razão para excluirmos o elemento apocalíptico desse cenário utópico. Se procurássemos por definições, poderíamos dizer que um projeto utópico não precisa ser necessariamente apocalíptico, podendo mesmo ser, sob circunstâncias outras que não as que nos ocupam aqui, até mesmo totalmente arreligioso. De igual modo, o anseio apocalíptico pode não ser utópico, na medida em que tais expectativas estejam colocadas totalmente numa ruptura da história que marcaria a chegada do eschaton, a consumação escatológica. Mas nada, fundamentalmente, impede que um projeto utópico seja atravessado por expectativas apocalípticas, numa conjunção que as condições específicas da primeira modernidade, com sua concentração exacerbada na esfera religiosa, tornavam quase obrigatória. Tal conjunção se manifesta sempre que o anseio apocalíptico aponta para uma concreção específica na história, ou seja, sempre que o próprio desenlace escatológico é imaginado no interior da história e não num "além" eterno. No caso do cerco sofrido pelos rebeldes de Münster, era esse elemento apocalíptico que comunicava, a esses fiéis, a certeza de que os tempos estavam cumpridos e de que, finalmente, as profecias se realizariam; era ele que permitia enfrentar a própria realidade do cerco, na medida em que o sofrimento dos justos, seguido de sua total libertação e glorificação, era lugar-comum em tais expectativas. Em suma, era esse componente a garantia de que todos os demais itens do ideário utópico encontrariam sua plena realização. ${ }^{19}$

\footnotetext{
${ }^{18}$ RODRIGUES, Rui Luis. Entre o dito e o maldito: humanismo erasmiano, ortodoxia e heresia nos processos de confessionalização do Ocidente (1530-1685). Tese de doutorado, Faculdade de Filosofia, Letras e Ciências Humanas, Universidade de São Paulo, São Paulo, 2012, p. 46-63.

${ }^{19}$ A discussão daquilo que tem sido chamado de "imaginação apocalíptica" é fundamental, mas não poderá ser desenvolvida nos limites deste artigo. Para uma introdução às origens da imaginação apocalíptica no judaísmo tardio dos séculos II a.C. - I d.C. ver COLLINS, John
} 
Entre os principais sinais dessa utopia temos, em primeiro lugar, a comunidade de bens. Aqui, aliás, estamos diante do que pode ser considerado o signo utópico por excelência da experiência dos visionários de Münster e uma indicação clara de seu cariz apocalíptico: seu afã de reviver a igreja dos Atos dos Apóstolos, em especial através da releitura dada a ela pela quarta epístola pseudo-clementina. ${ }^{20}$ Em Münster, a prática da partilha de bens não respondeu apenas ao difícil momento vivido pela cidade, mas encaixava-se perfeitamente no ideário de diversos desses grupos apocalípticos, cultores da ideia de um retorno ao que teria sido a vivência originária da fé cristã.

A poligamia foi outro elemento de caráter utópico presente no projeto münsterita. Não fez parte do projeto desde o início, sendo implantada a partir de maio de 1534, quando Jan Beukelzs, conhecido como Jan de Leiden, assumiu o controle da cidade em lugar de Jan Mathijs, discípulo de Melchior Hofmann morto em combate; mas não se constituiu em mera esquisitice. Ao contrário, ligava-se a representações bastante antigas, como as tradições de suprimento inesgotável das necessidades presentes na utopia da Cocanha. Ali, a sexualidade aparecia sempre nimbada por grande liberdade, o que parece indicar um anseio recorrente por realização sexual e superação da moral vigente. ${ }^{21}$

No caso dos anabatistas de Münster, a poligamia ganhava respaldo a partir de outra característica desse projeto visionário: o desejo de recuperar o locus vivencial do Antigo Testamento como ideal para a manifestação da nova sociedade divina. Esse ideal de recuperação do antigo Israel na formação de uma nova "república cristã" pode ser observado já nos inícios de 1534, quando os líderes anabatistas pressionaram os "sem Deus" a aceitar o sinal da aliança (o batismo de adultos) ou então a deixar a cidade. De acordo com Kerssenbrock, Mathijs teria dito nessa ocasião que era desejo de Deus que a "Nova Jerusalém" e seu santuário fossem "purificados da impureza" e que,

J. A imaginação apocalíptica: Uma introdução à literatura apocalíptica judaica. São Paulo: Paulus, 2010; VIELHAUER, Philipp. História da Literatura Cristã Primitiva: Introdução ao Novo Testamento, aos Apócrifos e aos Pais Apostólicos. Santo André: Academia Cristã, 2005, especialmente p. 513-55; COHN, Norman. Cosmos, Chaos, and World to Come: The Ancient Roots of Apocalyptic Faith. New Haven: Yale University Press, 1995; FRANCO JR., Hilário. A Eva Barbada: Ensaios de mitologia medieval. São Paulo: Edusp, 2010, p. 221-44 (última parte, "Mito e escatologia").

${ }^{20}$ Para as configurações do mito da comunidade de bens nas origens da igreja, ver especialmente Atos dos Apóstolos 2, 44 e 4, 32. Para o papel das cartas pseudo-clementinas (de cuja autenticidade ainda não se duvidava no século XVI) na configuração do imaginário anabatista relativo à comunidade de bens, ver WILLIAMS, George H. op. cit., 1983, p. 468-9.

${ }^{21}$ DAVIS, J. C. op. cit., 1985, p. 30. 
"matando-se papistas, luteranos, sacramentários e todos que discordavam de sua doutrina", a cidade fosse estabelecida "um único corpo e república". ${ }^{2}$ A medida foi, posteriormente, convertida em permissão para que os discordantes deixassem a cidade (e foi nessa ocasião que o próprio Kerssenbrock, ainda adolescente, viu-se forçado a partir). Mas a perspectiva revela a permanência de um quadro onde o corpo social era representado, em termos religiosos, como realidade homogênea; algo não muito distante das antigas formas medievais de representação do corpus christianum, exceto pelo fato de que, ali, desaparecia completamente a antiga e consagrada distinção entre poder civil e autoridade religiosa.

Semelhante ideário mobilizou boa parte da população de Münster numa dinâmica de grande teatralidade. Esse aspecto foi muito observado pelos adversários dos anabatistas; Kerssenbrock fala diversas vezes de Jan Beukelzs como um "rei teatral" e o faz de forma evidentemente pejorativa; ${ }^{23}$ mas há aqui uma dimensão muito mais séria a ser considerada. Estudos recentes têm frisado o caráter retórico presente no testemunho anabatista e, em especial, na maneira como tais grupos suportavam o martírio e não

\footnotetext{
22 "Finita hac concione toti multitudini proponit: Cum christiana haec respublica Patre divinitus sic dispensante feliciter coepta inter tot sectas, schismata et opiniones sine contentionibus et assidui seditionibus diu salva consistere non possit, Patrem itaque velle, ut nova haec Hyerosolima cum sanctuario a foeditate purgetur. Sibi ergo utile videri, ut papistis, Lutheranis, sacramentariis omnibusque a sua doctrina dissentientibus occisis unum corpus unaque respublica constituatur eaque novis ritibus et christianis legibus firmetur et stabiliatur, ut novo foederi initiati pacifice Patri serviant. Non enim a fece aliarum sectarum et impiorum contagione alio modo se immunes posse conservare, nisi impii occidantur" DETMER, H., op. cit., vol. II, p. 532-3. "Terminado o sermão, [Jan Matthys] explicou a toda a multidão que no meio de tantas seitas, cismas e opiniões, essa república cristã iniciada com tanta felicidade pela divina providência do Pai não poderia persistir sem contendas e repetidas sedições; e era desejo do Pai que essa nova Jerusalém com o santuário fossem purificados da impureza. Parecia a ele vantajoso, portanto, que, matando-se papistas, luteranos, sacramentários e todos que discordavam de sua doutrina, um único corpo e república fosse constituído e tornado forte e estável mediante novos ritos e leis cristãs, de modo que os iniciados na nova aliança servissem pacificamente ao Pai. Pois do contágio das outras seitas e dos ímpios não se poderiam conservar imunes, a menos que os ímpios fossem mortos"). Para a distinção formal entre magistratura civil e autoridade religiosa, mencionada a seguir, ver adiante, nota 36.

23 "Cum ante supplicium rex ille scenicus quibusdam principus spectandus fuisset exhibitus, reductus est Bevergernam atque illius arcis custodia firmiori concluditur" (Idem, vol. II, p. 869: "Foi decidido apresentar esse rei teatral a certos príncipes como espetáculo antes de sua execução, e para tanto ele foi levado a Bevergern e mantido na fortaleza sob estrita vigilância"); "ibique scenam extructam scenicus ille rex cum suis aulicis ascendens provolvitur in genua Patremque suo more iteratis vocibus invocat" (Idem, vol. II, p. 873: "e ali [na praça do mercado de Münster, no momento da execução] o rei teatral, juntamente com sua escolta, subiu ao palco que fora construído e, jogando-se sobre seus joelhos, repetidamente invocou à sua moda o Pai"), entre várias outras (os grifos são meus).
} 
raramente o procuravam. O representante da verdade, advogado da causa veritatis, via a si próprio no desempenho de um papel importantíssimo: o testemunho a ser dado e do qual ele devia se desincumbir. ${ }^{24}$ Para tanto, serviam os aparatos cênicos que deveriam reforçar, nos que assistiam, a compreensão de que estavam diante da manifestação da verdade. Em última análise, o próprio martírio se convertia em encenação cujo objetivo era oferecer a própria vida como a prova mais contundente possível da verdade do que se declarava. Uma atitude que se queria simples e transparente quando, de fato, era inteiramente retórica. ${ }^{25}$

É preciso lembrar que, nos inícios da fermentação religiosa que deu origem a esses anabatistas e a outros diversos movimentos (entre os quais, vários que nunca romperam com a Igreja católica), estavam as "câmaras de retórica" (rederijkerskamers) características dos Países Baixos: associações organizadas por vizinhos para as celebrações dos santos de uma localidade ou de outras datas do calendário litúrgico, em especial a festa de Corpus Christi, onde se escreviam e montavam peças teatrais e se declamavam produções literárias (daí o designativo "retórica"). Muitos sacramentários e anabatistas foram, primeiramente, rederijkers ou membros dessas câmaras, e o fato de Jan Beukelzs, antes de vir a Münster, ter sido membro de câmara de retórica e ator (além de alfaiate) torna essa ligação ainda mais nítida. ${ }^{26}$

Não há dúvida de que essa atitude retórico-teatral esteve presente entre os visionários de Münster. Beukelzs se fez coroar como "rei de justiça" em setembro de 1534 e procurou adotar um esplendor de corte digno do "reinado de Davi" que ele pretendia encarnar e que seria prévio ao reinado "salomônico" do Messias em seu retorno. Kerssenbrock fez pouco da teatralidade explícita da corte de Beukelzs, como forma de frisar sua ilegitimidade; mas, para os próprios anabatistas, obviamente a perspectiva era outra. Em outubro de 1534, Beukelzs ordenou a celebração de um grande festim que,

\footnotetext{
${ }^{24}$ SARTORELLI, Elaine Cristine. Estratégias de construção e de legitimação do ethos na causa veritatis: Miguel Servet e as polêmicas religiosas do século XVI. Tese de doutorado em Letras Clássicas, Faculdade de Filosofia, Letras e Ciências Humanas, Universidade de São Paulo, São Paulo, 2005, p. 76-7.

${ }^{25}$ Como Elaine Sartorelli observa em sua tese, o cristão "deveria comprovar diante de sua comunidade, com sua conduta no momento extremo, a veracidade daquilo que havia pregado" (Ibidem, p. 170; ver p. 170-1). Para Frank Lestringant, essa crença no poder comprobatório do martírio era partilhada tanto do lado protestante quanto do católico. Ver LESTRINGANT, Frank. Lumière des martyrs. Essay sur le martyre au siècle des Réformes. Paris: Honoré Champion, 2004, p. 113-6.

${ }^{26}$ De acordo com Kerssenbrock, previamente Beukelzs teria sido "ator ou arengador metido a retórico, proxeneta, taberneiro e alfaiate" ("rithmologum seu rhetoricastrum scenicum, lenonem, cauponem, sarcinatorem"). Ver DETMER, H., op. cit., vol. II, p. 690-1.
} 
no imaginário popular, assumiu as feições das Bodas do Cordeiro. Tratavase, para os anabatistas, de mais uma instância onde a representação, longe de parodiar de forma ilegítima uma realidade (como pensava Kerssenbrock), se constituía em veículo para sua manifestação concreta. Em suma, a presença do elemento teatral não significa que os atores desse drama não estivessem convictos do que criam e do que faziam. Tanto "retórico" quanto "teatral", para os anabatistas, não significavam falsidade ou representação no sentido dado a este último termo pelo senso comum. Tratava-se, sim, de "representação", mas no sentido clássico do termo, no qual seus atores tornavam presente uma realidade ausente; ao assumirem a execução dos propósitos divinos, eles entendiam que se tornavam os veículos através dos quais o reino escatológico finalmente se concretizava. ${ }^{27}$

Cabe lembrar, de resto, que não apenas para os anabatistas de Münster, mas para aquela sociedade como um todo, a representação era uma dimensão importantíssima da existência. A necessidade de tornar público cada ato e o recurso às gestualidades rituais eram generalizados. Basta pensar na execução dos três líderes da revolta de Münster que sobreviveram à retomada da cidade em 25 de junho de 1535: Jan Beukelzs, Bernardo Knipperdoling e Bernardo Krechting foram torturados em praça pública com tenazes em brasa e, após executados (22 de janeiro de 1536), foram colocados em gaiolas de ferro que permaneceram suspensas na torre da igreja de São Lamberto; ali os corpos apodreceram e, mesmo depois de terem desaparecido os ossos, as gaiolas continuaram penduradas como forma de lembrança e aviso. ${ }^{28} \mathrm{O}$ suplício público era prática corrente e incluía esse âmbito de representação catártica: os condenados eram supliciados concretamente, mas a ocasião servia para a purificação de todo o corpo social. No caso de Münster a teatralidade alcançou proporções inauditas, com o recurso tradicional à exposição dos corpos dos condenados empregado de forma totalmente nova: os cadáveres não foram removidos após algum tempo; em 1888, as gaiolas, já deterioradas pela exposição às intempéries, mas ainda penduradas na torre, foram substituídas por cópias exatas que ainda podem ser vistas no Stadt-

\footnotetext{
${ }^{27}$ Idem, vol. II, p. 697-703. Para os problemas em torno do conceito de "representação", ver GINZBURG, Carlo. Representação: a palavra, a ideia, a coisa. In: Idem. Olhos de madeira: Nove reflexões sobre a distância. São Paulo: Companhia das Letras, 2001, p. 85-103 (que, todavia, não se ocupa da representação cênica).

${ }^{28}$ Idem, vol. II, p. 870-6. Outras fontes do período apresentam pequenas discordâncias em relação ao relato de Kerssenbrock.
} 
Museum de Münster. Outras réplicas, feitas em 1898, ainda podem ser vistas na torre da igreja de São Lamberto. ${ }^{29}$

Diante dos arroubos visionários presentes no episódio de Münster, haverá quem duvide de que a designação "utopia" possa ser aplicada ao episódio do cerco sofrido pela cidade de Sancerre entre janeiro e agosto de 1573, descrito no texto sóbrio de Jean de Léry. Mas, como veremos, a aparente e por vezes trágica sobriedade do texto de Léry oculta de nós aspectos importantes e, por isso, merece ser sondada criticamente.

O texto, publicado em Genebra no ano de 1574 e que experimentou ampla divulgação, traduzido para o alemão e para o neerlandês em 1575 e para o latim em 1576, começa louvando a firmeza dos habitantes de Sancerre na fé huguenote; em consequência disso, a cidade teria se tornado alvo do ódio dos católicos quando, entre agosto e outubro de 1572, as tensões religiosas explodiram nas turbulências da "saison de la Saint-Barthélemy". ${ }^{0}$ Os massacres provocaram a ida de muitos refugiados calvinistas para Sancerre, entre os quais o próprio Léry, então pastor da comunidade huguenote em La Charitésur-Loire. A cidade recebeu vários ultimatos do rei ordenando o imediato abandono da fé calvinista e o estabelecimento, nos limites urbanos, de uma guarnição militar comandada por um lugar-tenente do rei; note-se que esta última exigência contrariava os privilégios forais adquiridos por Sancerre. A recusa terminante da cidade de atender às ordens reais causou o início do cerco propriamente dito, a 9 de janeiro de 1573. Em abril a fome já grassava na cidade totalmente isolada; ponto culminante do relato de Léry, essa fome

\footnotetext{
${ }^{29}$ MACKAY, Christopher S. op. cit., 2007, p. 75.

${ }^{30}$ LESTRINGANT, Frank. Léry ou Le rire de l'Indien. In: LÉRY, Jean de. Histoire d'un voyage faict en la terre du Bresil [1578]. Texte établi, présenté et annoté par Frank Lestringant. Paris: Le Livre de Poche, 1994, p. 15-39, aqui p. 37-38; JOUANNA, Arlette; BOUCHER, Jacqueline; BILOGHI, Dominique; LE THIEC, Guy (ed.). Histoire et Dictionnaire des Guerres de Religion. Paris: Éditions Robert Laffond, 1998, p. 1031-2; CROUZET, Denis. La nuit de la Saint-Barthélemy. Un rêve perdu de la Renaissance. Paris: Fayard, 1994; Idem. Les guerriers de Dieu. La violence au temps des troubles de religion, vers 1525-vers 1610. Seyssel: Champ Vallon, 1990. 2 v.; WHATLEY, Janet. Food and the Limits of Civility: The Testimony of Jean de Léry. The Sixteenth Century Journal, vol. 15, n. 4, 1984, p. 387400. Ver a edição, com estudo introdutório, de Géralde Nakam para o texto de Jean de Léry. NAKAM, Géralde. Au lendemain de la Saint-Barthélemy, guerre civile et famine. L'Histoire mémorable du siège de Sancerre (1573). Paris: Anthropos, 1975. O cerco de Sancerre começou de fato a 9 de janeiro de 1573 (ver LÉRY, Jean de. op. cit., 1574, p. 69), mas desde setembro de 1572 os emissários do rei tentavam obter o controle da cidade (ver Ibidem, p. 1-68).
} 
é descrita em detalhes, com ênfase para o caso de canibalismo ali perpetrado e que foi julgado pelos magistrados locais. ${ }^{31}$

O cerco terminou, finalmente, em agosto de 1573, com a capitulação de Sancerre após as negociações, nas quais Léry desempenhou papel importante. Ele teve, aliás, sua saída da cidade garantida pelo representante do rei, após a rendição; todavia, os termos do acordo não foram totalmente honrados e vários dos líderes da cidade durante o cerco foram posteriormente executados. A fé huguenote restou proibida e o clero católico foi restabelecido. ${ }^{32}$

$\mathrm{O}$ que nos permite afirmar que, nesse ambiente, desenvolveu-se um projeto utópico? É preciso considerar, em primeiro lugar, que o calvinismo a que se atinham Léry e os reformados de Sancerre possuía uma dinâmica interna que merece ser caracterizada como utópico-apocalíptica e cujas diferenças de tom e de configuração em relação aos apocalípticos de Münster não pode ocultar as semelhanças de fundo. Mais do que qualquer outro projeto de reforma da igreja no século XVI, o calvinismo visou uma reforma da sociedade. "Trazer o mundo à ordem" era o que Calvino concebia como sendo a tarefa dos ministérios ordenados na Igreja. ${ }^{33}$ Se identificarmos "utópico" com "ingênuo e irrealizável", como faz frequentemente o senso comum, certamente desistiremos de encontrar qualquer sinal de utopia no ideário calvinista, que considerava naturais as distinções sociais, não abominava as riquezas (apesar de advertir muitas vezes sobre seus perigos), sabia ser inevitável a passagem para a sociedade urbana e a economia mercantil e manifestava tamanho senso prático ao ponto de defender o uso de enganos e estratagemas nas guerras. ${ }^{34}$ Nada disso elimina de seu sistema, todavia, a presença de fermentos utópicos, evidentes na sua intenção de promover, na sociedade, um reordenamento que obedecia a diretrizes escatológico-apocalípticas: é como "nova Jerusalém", como modelo de convívio humano para o resto do mundo, que a cidade reformada deve se colocar.

\footnotetext{
${ }^{31}$ Trata-se do capítulo X da Histoire memorable, "De l'extreme famine, cherté de viures, chairs \& autres choses non accostumees pour la nourriture de l'homme, dont les assiegez dans la ville de Sancerre ont este affligez, E ont use enuiron trois mois" (p. 129-64).

32 LÉRY, Jean de. op. cit., 1574, p. 188-228.

33 BOUWSMA, William J. John Calvin: A sixteenth-century portrait. Oxford: Oxford University Press, 1988, p. 191.

${ }^{34}$ BOUWSMA, William J. op. cit., 1988, p. 194-7.
} 
Para Calvino, os âmbitos da igreja e da magistratura eram distintos ${ }^{35}$; reis piedosos deveriam deixar à igreja o controle dos assuntos eclesiásticos. Os magistrados, por sua vez, estavam investidos de uma autoridade derivada da própria realeza de Cristo. Por isso, deveriam promover a glória de Deus através da policia, a manutenção de uma ordem prática na sociedade. Assim, a um objetivo final de caráter teológico (a glória de Deus, servida pela constituição de corretas relações entre os homens) subordinavam-se todas as instâncias do corpo social; embora distinta da magistratura, a igreja se constituía na sua "consciência", por assim dizer, e assumia o encargo de encaminhar o projeto teológico-político de construção da sociedade.

O projeto calvinista parece dotado de maior respeito pelas dinâmicas jurídico-políticas próprias da cristandade latina, em especial a separação entre as esferas civil e religiosa ${ }^{36}$ sobretudo quando comparado às reformas conduzidas em Zurique e Estrasburgo. Nessas cidades, como Prodi observa, nota-se "uma ligação maior e, às vezes, uma fusão entre a magistratura civil e a religiosa: nas novas Jerusaléns citadinas, o sistema de representação impede já desde a base uma separação entre o corpo da Igreja e o corpo da sociedade civil". ${ }^{37}$ Mas a solução calvinista ocultava um golpe fatal no dualismo de esferas, na medida em que a Igreja, como consciência da magistratura, efetivamente ditava "os princípios da convivência social". ${ }^{8}$ Aquele "caminho de uma colaboração orgânica, no plano de igualdade, entre a estrutura eclesiástica e civil", que para Prodi teria sido adotado em Genebra e que, conquanto "mais difícil" que os de Zurique e Estrasburgo, teria sido o de "mais sucesso", 39 parece render-se de fato à preponderância do elemento religioso. Se, como pretende Prodi, o "mito de Florença como nova Jerusalém"40 teria exercido uma influência importante sobre essas reformas citadinas, ao fornecer a elas um modelo de religião cívica, parece claro que é a figura de

\footnotetext{
35 Ibidem, p. 204; CALVINO, João. A Instituição da Religião Cristã. São Paulo: Editora Unesp, 2009, livro IV, capítulo xx. 2 v., vol. 2, p. 875-902.

${ }^{36}$ PRODI, Paolo. Uma história da justiça: Do pluralismo dos foros ao dualismo moderno entre consciência e direito. São Paulo: Martins Fontes, 2005, especialmente p. 1-354 (capítulos I-VI); SCHILLING, Heinz. Early modern european civilization and its political and cultural dynamism. The Menahem Stern Jerusalem Lectures. Lebanon: University Press of New England, 2008, p. 13-32 e p. 67-86.

${ }^{37}$ PRODI, Paolo. op. cit., 2005, p. 257. Ver p. 254-61 ("A cidade, nova Jerusalém"), especialmente p. 256-7, para a presença do fermento escatológico nesses projetos citadinos de reforma, incluído aí o projeto calvinista.

${ }^{38}$ Ibidem, p. 257.

${ }^{39}$ Ibidem, p. 257.

${ }^{40}$ Ibidem, p. 256.
} 
Calvino, com sua defesa da tutela da magistratura pela Igreja, e não a de Zwinglio, com sua aceitação da submissão eclesiástica às autoridades citadinas, aquela que mais se assemelha ao perfil de Savonarola.

É essa perspectiva, desenvolvida numa direção ainda mais nitidamente utópica, que encontraremos em Léry. As disposições de autogestão dos cidadãos de Sancerre ficam claras em diversas passagens do texto (o que, mais uma vez, estava de acordo com as práticas forais e as estruturas polissinodais), mas aparecem especialmente no capítulo vi; ${ }^{41}$ vemos aqui a preocupação com a ordem, característica da perspectiva calvinista, conjugada à busca da correta policia que deveria espelhar a santidade da fé. É sintomática, nesse sentido, a preocupação com a eliminação dos vícios e de práticas consideradas nocivas, como o juramento indiscriminado e as blasfêmias. ${ }^{42}$ Também é digno de nota que, a darmos crédito ao testemunho de Léry, mesmo em meio às dificuldades do cerco a cidade tivesse mantido um nível elevado de organização. Promulgavam-se medidas sempre que necessário e os magistrados não se furtavam ao exercício de seus deveres: os pais acusados de devorar o cadáver da filha, exemplo supremo do desespero do cerco e que Léry narra com tenso dramatismo, foram executados apenas após o julgamento. Ao mesmo tempo, a dimensão religiosa também se encontrava ordenada, independentemente das magistraturas seculares, e ocupada em julgar os assuntos ligados à igreja: era esse o papel do consistório. Léry nos dá um exemplo dessa sanha controladora ao mencionar a relação traçada pelo consistório de Sancerre entre o "comportamento desordenado" do casal acusado de canibalismo e o próprio ato que teriam praticado: oriundo de outra cidade, o casal não seria legitimamente casado; na ausência de comprovação da morte do ex-marido da mulher, a igreja reformada recusara-se a legalizar a união e o casal teria ido se casar "à la papauté", demonstrando não apenas inconstância moral mas, também, instabilidade religiosa. O fato de, pouco antes da ocorrência do episódio de canibalismo, esse casal ter recebido ração extra de alimento, indicaria também o desordenamento de suas paixões. O episódio, emblematicamente, nos mostra a superposição entre as esferas religiosa e civil: são os magistrados da cidade, e não o consistório, que condenam os acusados de canibalismo à morte; mas o consistório acompanha o processo, julga a conduta dos acusados, fornece a explicação religiosa

\footnotetext{
${ }^{41}$ "De l'ordre E' gouernement qui fut mis en la ville de Sancerre pour s'opposer à ceux qui la vouloyent forcer, $\mathcal{E}$ de quelques sorties E escarmouches". Cf. LÉRY, Jean de. op. cit., 1574, p. 57-68.

${ }^{42}$ Ibidem, p. 62.
} 
para a transgressão e, por assim dizer, "guia a mão" do carrasco civil. Ainda que, evidentemente, a crônica do cerco não possa ser tomada como reflexo cristalino da situação que se passava em Sancerre, ela nos fornece exemplo marcante de como, de acordo com as concepções de Léry, as relações entre magistratura, Igreja e povo deveriam funcionar. ${ }^{43}$

O caráter utópico é reforçado, no caso do relato de Léry, pela identificação que ele enxerga entre a igreja reformada e o antigo povo de Israel. Para Léry (e ele dava expressão a uma convicção tipicamente calvinista, como se percebe pela recorrência desse topos noutros locais), a igreja encontrava-se na continuidade em relação ao antigo Israel e era alvo da atenção especial de Deus, por conta de sua vocação a agir como testemunha das obras divinas em toda a terra; daí porque ela seria objeto de livramentos operados pela providência. ${ }^{44}$ Ainda que numa forma algo transfigurada, reencontramos no calvinismo a mesma obsessão pelo Antigo Testamento que observamos entre os anabatistas de Münster; efetivamente, teologia, imaginário religioso, formas de devoção e projeto teológico-político dos calvinistas foram muito marcados pela maneira como eles compreendiam e procuravam recuperar o locus vivencial dos antigos israelitas. ${ }^{45}$

Em Léry, todavia, essa dinâmica utópica, que reencontraremos alhures em diversas formulações ligadas de uma forma ou de outra ao calvinismo, aparece numa luz muito particular. As próprias condições do cerco levaram esse autor, como veremos, a uma reflexão sobre o fracasso do projeto no qual estava envolvido. Nutridas nos espaços urbanos, tanto em Münster quanto em Sancerre, as utopias são postas à prova pela dura realidade do cerco.

\footnotetext{
${ }^{43}$ Ibidem, p. 145-54, especialmente p. 149-50 (para a referência ao casamento "à la papauté"). Ver adiante nota 71 .

${ }^{44}$ Ibidem, p. 106. Trata-se, de acordo com Léry, do cântico de ação de graças (p. 103-6) entoado em Sancerre por ocasião de uma vitória sobre os sitiadores.

45 Trata-se de uma tópica que dominou em especial o "puritanismo", e principalmente aquele transplantado para as colônias inglesas da América do Norte, mas que não se limitou de forma alguma a ele. Ver MATHER, Cotton. Magnalia Christi Americana or, The Ecclesiastical History of New England from its First Planting in the Year 1620 unto the Year of Our Lord, 1698. London: Thomas Parkhurst, 1702; HALL, David D. Worlds of Wonder, Days of Judgement: Popular Religious Beliefs in Early New England. New York: Knopf, 1989; FOSTER, Stephen. The Long Argument: English Puritanism and the Shaping of New England Culture, 1570-1700. Chapel Hill: University of North Carolina Press, 1991.
} 


\section{A utopia sitiada}

Hermann von Kerssenbrock compôs seu texto, provavelmente, a partir de 1564, quando já era reitor da escola catedralícia de Münster desde 1550. Tendo retornado a essa cidade logo após sua retomada, ele sempre foi um homem profundamente comprometido com a Igreja Católica e foi a partir dessa perspectiva que escreveu sua obra.

É preciso ter em mente não apenas esse fato, mas também seus desdobramentos, para que possamos entender o papel que a Narratio de Kerssenbrock desempenhou em termos de contrapropaganda; ou, ao menos, o papel que seu autor teria desejado que ela desempenhasse. O livro obedece a duas diretrizes básicas: a primeira é demonstrar como o escândalo de Münster não foi causado apenas pelo delírio anabatista; esse delírio é que teria sido provocado pela simpatia demonstrada pelo Conselho da cidade em relação ao luteranismo durante a década de 1520. Quando Kerssenbrock iniciou a escrita de sua obra, o luteranismo voltara a contar com muitos simpatizantes na cidade, tal como ocorrera antes da rebelião; daí porque o autor insiste em afirmar que foi dos "distúrbios que precederam o rebatismo" (ou seja, das tentativas feitas ao longo da década de $1520 \mathrm{em}$ prol de uma reforma de cunho luterano) que a subversão de Münster emergiu "como que de um cavalo de Troia". ${ }^{46}$

A segunda diretriz relaciona-se com as intensas disputas pelo poder travadas entre, de um lado, o príncipe-bispo apoiado pelo capítulo catedralício e, de outro, as instâncias municipais de poder, representadas pelo Conselho sob o controle das guildas e dos grêmios comerciais existentes na cidade. Que o desejo do príncipe-bispo era fortalecer seu poder em detrimento desses outros foros fica claro pelo que se seguiu à retomada da cidade: em 1536, uma guarnição foi estabelecida em seu interior e várias medidas foram adotadas para prevenir qualquer futura sedição e desobediência. ${ }^{47}$ Tais medidas cerceavam liberdades e privilégios tradicionais da cidade, dando ocasião a disputas entre o Conselho e o príncipe que só foram resolvidas, com mediação imperial, em $1553 .^{48}$

\footnotetext{
${ }^{46}$ DETMER, H., op. cit., vol. I, p. 6. Ver também vol. I, p. 4, 114, 334 e vol. II, p. 379.

${ }^{47}$ Idem, vol. II, p. 878-85.

${ }^{48}$ Idem, vol. II, p. 897-950. Ver vol. II, p. 945-7 para a transcrição do documento, datado de maio de 1553, em que o príncipe-bispo finalmente devolve à cidade "suas antigas e louváveis liberdades e privilégios civis" ("omnes antiquas et laudabiles libertates et civilia privilegia", p. 945).
} 
De um lado, portanto, a propaganda contra-utópica de Kerssenbrock estava comprometida com a religião católica em luta não apenas com formas religiosas "extremas", como os movimentos anabatistas, mas com a "ameaça luterana" de modo bem específico. Isso situa o esforço de Kerssenbrock no ambiente da confessionalização católica pós-Concílio de Trento. De outro lado, Kerssenbrock posicionava-se a favor de dinâmicas políticas novas, como é o caso das tentativas principescas de centralizar o poder, contra as formas tradicionais, corporativas, de gestão política (representadas pelo Conselho citadino e pelas guildas e grêmios). Foram esses os fatores que compuseram o quadro social, complexo, no qual se desenvolveu a leitura que Kerssenbrock fez da rebelião em Münster, mais de trinta anos depois dos eventos.

O esforço contra-utópico de Kerssenbrock se articula no texto, primeiramente, pela tentativa de desqualificar o que se passava em Münster a partir do recurso aos topoi do descontrole, da devassidão e do orgulho (a desmedida, hybris). São emblemáticas as descrições que Kerssenbrock faz do descontrole das mulheres anabatistas, que corriam pelas ruas com os cabelos soltos e em desalinho, os corpetes dos vestidos abertos, as bocas espumando, presas de reações emocionais contraditórias que as levavam a rir, chorar, gritar, revolver-se no solo e aplaudir. ${ }^{49}$ É significativo que Kerssenbrock retrate especificamente o comportamento das mulheres: para os parâmetros daquela sociedade, seriam elas, justamente, as que deveriam ser protegidas pelos homens, dada sua condição de fragilidade; assim, a loucura dos pregadores anabatistas era responsável pela loucura, ainda mais desenfreada, de suas discípulas.

Ao procurar descrever a devassidão que atribui aos anabatistas, Kerssenbrock superou a si mesmo na reprodução de estereótipos: alcunhada de "batismo de fogo", a "orgia", conduzida numa casa particular para onde eram levados os recém-batizados, acontecia à noite, com as luzes apagadas e após um discurso destinado a excitar as paixões dos ouvintes. ${ }^{50} \mathrm{O}$ topos da licenciosidade do herege, lembremos, é tão antigo quanto o cristianismo; de fato, foi usado pelos romanos contra os cristãos e, depois, empregado por estes contra praticamente todos os movimentos heterodoxos posteriores. ${ }^{51}$

\footnotetext{
${ }^{49}$ Idem, vol. II, p. 500-2.

${ }^{50}$ Idem, vol. II, p. 512.

${ }^{51}$ Para a tópica da relação entre heresia e licenciosidade, ver RODRIGUES, Rui Luis. op. cit., 2012, p. 541-4 (com bibliografia).
} 
A desmedida aparece sob formas mais sutis que o descontrole feminino e a devassidão: Kerssenbrock se lembrou de afirmar, com relação a Jan Beukelzs, já então autodenominado "rei de justiça", que ele, "esquecendo completamente sua origem e primitivo modo de vida, diariamente procurava novas formas de ressaltar sua dignidade real, sendo cruel e selvagem para com seus súditos".52 Impossível uma referência mais cristalina ao topos clássico da hybris: o abandono de sua própria posição no organismo social, por conta da loucura suscitada pelo orgulho. A falsidade das alegações de Beukelsz restaria sublinhada pela referência à maneira pela qual ele tratava os súditos, contrária ao que tradicionalmente se esperava do príncipe. Ao descrever a morte de Jan Mathijs num confronto com os sitiadores, Kerssenbrock associa-a também ao orgulho: convencido de que Deus lhe daria vitória, Mathijs aventurou-se numa incursão temerária e terminou varado pela lança de um soldado. ${ }^{53}$

Essas alegações se prestam a colocar a utopia sub judice; a partir delas, Kerssenbrock desenvolve seu argumento acerca dos perigos de uma vitória dos anabatistas. Descrevendo os esforços do príncipe-bispo Francisco de Waldeck em busca de apoio militar dos demais príncipes do Império contra os anabatistas, Kerssenbrock mostra como esse perigo foi pintado pelos representantes do bispo com cores fortes diante da Dieta Imperial reunida em Koblenz (dezembro de 1534): os anabatistas pretendiam subverter não apenas a diocese de Münster, mas toda a Germânia e, se fossem deixados livres, submeteriam a si, pelo fogo e pela espada, todos os príncipes cristãos ${ }^{54} \mathrm{em}$ razão disso, suplicava-se aos demais príncipes do Império que avaliassem diligentemente essa terrível e perigosa situação e não permitissem que um novo reino Turco deitasse raízes no meio da Cristandade. ${ }^{55} \mathrm{O}$ cerco precisava ser entendido

\footnotetext{
52 "Rex recenti victoria inflatus fastum intolerabilem ornatu, incessu et moribus ostentat ac originis vitaeque suae pristinae immemor et oblitus quotidie nova, quae ad regium decus illustrandum pertinent, comminiscitur, saevus et crudelis in subditos". DETMER, H., op. cit., vol. II, p. 687.

${ }^{53}$ Idem, vol II, p. 478-9 (para breve menção às pretensões proféticas de Mathijs e à sua morte) e vol. II, p. 568-70 (para uma descrição detalhada).

${ }^{54}$ Idem, vol II, p. 743.

55 "Quare status, legatos et consiliarios superiorum principum et provinciarum trium, quotquot his comitiis intersint, suum principem rogare atque obsecrare, ut horrendam hanc causam simul et periculosam diligenter secum expendant neque novum regnum Turcicum in medio christiani orbis coalescere sinant" ("Pelo que [pedia-se] aos vários legados e conselheiros superiores dos príncipes das três províncias ali presentes, rogar e suplicar, cada um a seu próprio príncipe, que avaliassem cuidadosamente essa situação tão horrenda quanto perigosa, e não permitissem que um novo reino Turco deitasse raízes no meio da Cristandade". Idem, vol. II, p. 744).
} 
como medida profilática, como a única maneira de impedir o avanço de um câncer terrível sobre a totalidade do Império e do restante da Europa cristã.

Como parte da mesma estratégia propagandística, a tragédia de Münster, especialmente os sofrimentos da população por conta da fome, foi mostrada por Kerssenbrock, com o emprego dos referenciais clássicos adequados (em especial, o uso do cerco de Jerusalém, retratado por Flávio Josefo), de forma a sublinhar os resultados terríveis da "loucura anabatista". O relato vai num crescendo, da matança de animais como cavalos e potros para alimentação, passando por camundongos, ratos e arganazes, pelos cães (cuja ingestão já é referida com estranheza), pelo consumo de couros de sapatos e capas de livros, pelas tentativas de se comer excremento, até chegar ao topos, também clássico, do canibalismo. "Mu "Muitos bebês morriam nos braços de suas mães e muitos, tremo só de dizer isto, eram mortos à espada por seus próprios pais para servirem de alimento, e após a captura da cidade, não só em um, mas em vários locais, os ossos desses bebês foram encontrados em salmoura", escreve Kerssenbrock, que acrescenta: "Ao não se refrear de comer sua própria ninhada, esse povo ultrapassou todos os animais em selvageria e desumanidade".57

A esse quadro Kerssenbrock liga, diretamente, o tema da decepção. Segundo ele, alguns,

dando crédito às promessas do rei [Beukelzs], estavam confiantes de que o Pai celestial transformaria as pedras do calçamento em broas de pão, antes que eles morressem de inanição. Por isso, quando se viam atormentados pela fome, tentavam morder essas pedras, mas ao perceberem pela experiência que nenhuma modificação se operara nos

\footnotetext{
${ }^{56}$ Idem, vol. II, p. 797-803.

57 "Multos infantes aut in cunis aut in sinu matrum auxilii expertium fames absumit et enecat, multos quoque (horresco referens) parentum gladius cibi causa extinguit, quorum membra post captam urbem non in uno, sed pluribus locis urbis in salsugine reperta sunt. (...) At hi a proprii partus cibo non abhorrentes omnes bestias acerbitate et immanitate superant". Idem, vol. II, p. 800-2. Para a importância dos relatos de canibalismo enquanto "chave mítica", no contexto quinhentista, bem como para as referências clássicas ao tema, ver LESTRINGANT, Frank. Une sainte horreur ou le voyage en Eucharistie, XVI ${ }^{e}$-XVIII ${ }^{e}$ siècle. Paris: Presses Universitaires de France, 1996, p. 63; ver também, adiante, nota 65. Conquanto as referências a atos de canibalismo compusessem tópica frequente nas descrições de cercos militares, a narrativa de Kerssenbrock sobre sua ocorrência em Münster não é respaldada por nenhum documento coetâneo.
} 
acidentes ou na substância das mesmas, sua fé começava a vacilar e silenciosamente, em lágrimas, lamentavam-se por terem sido tão terrivelmente desencaminhados. ${ }^{58}$

A decepção era um importantíssimo argumento para a propaganda contra-utópica, permitindo assinalar o equívoco cometido pela população e suas consequências cruéis. Em contraste com a ênfase na crescente decepção entre os habitantes sitiados, podemos incluir as menções que Kerssenbrock faz ao renovado zelo da população pela fé católica após a retomada da cidade. Kerssenbrock observa: “Depois, clero e cidadãos competiram entre si para reparar as igrejas e restaurar o serviço divino com esforços muito maiores do que aqueles despendidos pela gente deplorável que os destruíra e abolira". ${ }^{59}$ Ao mencionar a reconsagração da catedral de São Paulo, em dezembro de 1538, ele acrescenta: "o culto divino e todas as cerimônias católicas foram revividos com zelo sem paralelo por parte dos cidadãos". ${ }^{60}$ Ao tumulto infernal causado pela "loucura" anabatista era preciso contrapor o zelo enfático, conquanto estável e sereno, que teria marcado a restauração da fé católica.

A obra de Kerssenbrock, concluída para publicação em 1573, permaneceu inédita, tendo sido proibida pelo Conselho de Münster, que se sentiu indevidamente representado na narrativa por conta da maneira como o autor descreveu os conflitos entre os cidadãos e o príncipe; sua primeira impressão antes da edição crítica de Detmer (1899-1900) ocorreria apenas em 1771, numa tradução alemã bastante deficiente. ${ }^{61}$ Mas restam da obra original diversos manuscritos completos, o que mostra que ela experimentou relativa divulgação sob essa forma.

Todavia, mesmo considerando os percalços da publicação e essa circulação limitada, não se deve duvidar da força potencial dessa propaganda contra-utópica. Escrita décadas após o evento que narra, mas dentro de um contexto onde a polêmica católica teria como fazer bom uso de sua descrição, ela

\footnotetext{
58 "Quidam promissione regis freti eam habent fiduciam, ut, priusquam fame intereant, Patrem saxa platearum in panes transformaturum credant; ideoque, cum horrenda esurie torquerentur, morsibus silices pertentant; at ubi neque substantiae neque ullius accidentis metamorphosin factam experirentur, fiducia illa pristina flaccessit, et flentes miserrime se esse subductos tacite queruntur". DETMER, H., op. cit., vol. II, p. 803.

59 "Post haec clerus et cives certatim maiori studio templorum reparationi et divini cultus restaurationi, quam homines illi deplorati destructioni et abolitioni intenti in hoc potissimum incubuere". Idem, vol. II, p. 876.

60 "divinus cultus omnesque ceremoniae catholicae singulari omnium civium pietatis studio et applausu revirescunt". Idem, vol. II, p. 897.

${ }^{61}$ KERSSENBROCK, Hermann von. Geschichte der Widertäufer zu Münster. Münster: 1771. Para uma síntese dos percalços enfrentados pelo texto de Kerssenbrock, ver MACKAY, Cristopher S. op. cit., 2007, p. 39-47.
} 
se tornou referência para outras tentativas de exaltação do status quo religioso e social contra quaisquer propostas de transformação. Em 1853, um nobre francês, católico ferrenho e igualmente conservador em matéria de política, Marie-Théodore Renouard, visconde de Bussierre, profundamente assustado com os impactos das revoluções de 1848, serviu-se largamente da obra de Kerssenbrock, lida por ele na tradução alemã de 1771, para escrever sua obra Les Anabaptistes: Histoire du Luteranisme, de l'Anabaptisme et du regne de Jean Bockelsohn a Munster. ${ }^{62}$ Enquanto para Kerssenbrock o luteranismo fora a matriz de onde emergira a desgraça anabatista, para o conservador visconde de Bussierre desse mesmo ventre brotara, séculos depois, a ameaça comunista. "Os inovadores do século XVI", escreveu ele, "abriram a porta a todas as desordens e aos mais monstruosos excessos, no dia em que se libertaram do jugo tutelar da Igreja"63. Ele concluiu: "a aplicação ampla e completa do sistema que se chama hoje comunismo e socialismo foi o resultado imediato dessas doutrinas ímpias e insensatas; ele surgiu pela primeira vez na capital da Vestfália". ${ }^{64}$

Enquanto para os anabatistas de Münster o isolamento provocado pelo cerco era o caminho difícil a se atravessar até a realização plena dos eventos apocalípticos, para os calvinistas franceses o isolamento era uma realidade mais ambígua. Jean de Léry percebeu claramente que aquela situação de insularidade, provocada pelo cerco, se constituía no principal obstáculo para a implantação da nova ordem. Para ele, Sancerre repetia, no nível micro, a realidade dos huguenotes em território francês: eleitos por Deus, mas minoritários e cercados de inimigos por todos os lados. Porque, se de fato a "insularidade" acabava sendo uma condição recorrente na expressão literária de muitas utopias (em geral descritas como ilhas, ou como montanhas retiradas, ou como planetas, ou simplesmente como cidades com seus limites bem definidos), aqui a insularidade se tornou o elemento que inviabilizava o projeto utópico: o drama da fome, que obrigou os moradores da cidade a consumirem as coisas menos consumíveis e, finalmente, a praticarem o

\footnotetext{
${ }^{62}$ BUSSIERRE, Marie-Théodore Renouard, Vicomte de. Les Anabaptistes: Histoire du Luteranisme, de l'Anabaptisme et du regne de Jean Bockelsohn a Munster. Plancy/Paris: Société de Saint-Victor pour la propagation des bons livres/Sagnier et Bray, Libraires, 1853.

${ }^{63}$ BUSSIERRE, Marie-Théodore Renouard, Vicomte de. op. cit., 1853," p. I ("Les novateurs du seizième siècle ont ouvert la porte à tous les désordres et aux plus monstrueux excès, le jour où ils se sont affranchis du joug tutélaire de l'Église").

${ }^{64}$ Ibidem, p. II ("l'application large et complete du système qu'on nomme aujourd'hui communisme et socialisme a été le résultat immédiat de ces doctrines impies et insensées; elle a été faite pour la première fois dans la capitale de la Westphalie"; os grifos são do autor).
} 
"curto-circuito" representado pela ingestão da carne humana, serve como símbolo para esse isolamento que enfraquece os homens e inviabiliza a realização de seus projetos. ${ }^{65}$

Mas a ambiguidade do isolamento se mostra no fato de que, dadas as condições específicas enfrentadas no território francês, a insularidade também representava a força que os calvinistas podiam, naquele contexto, possuir: em menor número e incapazes de enfrentar as tropas do rei em campo aberto, dependiam de fortificar as cidades que controlavam; de igual modo, essa circunscrição ao espaço urbano bem delimitado oferecia a possibilidade de um controle mais estrito das consciências, pela pregação e pela vigilância. "C'est dans la ville close", escreve Frank Lestringant, "que le protestantisme a son lieu naturel" e onde, de mais a mais, "la prédication évangélique a le plus d'efficacité". 66

Essa força que dependia da insularidade era, contudo, bastante incerta. O que transparece com muita clareza do texto de Léry é a percepção de que, a essa pressão de natureza externa constituída pelo cerco e que impunha as dificuldades do isolamento, era preciso juntar outra, de natureza interna. Para Léry, foram os vícios dos homens, dos seus próprios correligionários calvinistas, que atraíram sobre eles o juízo de Deus. O povo teria tido todas as chances de implementar uma existência piedosa naquela cidade, mas abrira mão dessa oportunidade por causa da indolência; além disso, mesmo sob a provação do cerco eles davam lugar à avareza: em meio aos sofrimentos e à penúria quase total, e apesar das tentativas, sempre frustradas, do governo da cidade para tabelar os alimentos, os habitantes de Sancerre vendiam a preços exorbitantes qualquer coisa que pudesse ser comida. ${ }^{67} \mathrm{Na}$ leitura providencialista do pastor Léry está clara a noção de que, tivessem os calvinistas de Sancerre agido de forma menos egoísta, a mão divina os teria ajudado; a ameaça externa teria sido vencida com o auxílio divino expectativa que, de resto, era sustentada pela matriz providencialista do próprio cerco de Jerusalém pelos babilônios, apresentado no texto bíblico como castigo divino contra as prevaricações dos judeus e cujo relato, ao lado da história do cerco de Jerusalém pelos romanos, narrada por Flávio Josefo, constituiu um dos interdiscursos de que Léry lançou mão. ${ }^{68}$

\footnotetext{
${ }^{65}$ LESTRINGANT, Frank. op. cit., 1996, p. 71. Para a tópica do canibalismo, ver ainda p. 39-59 e p. 61-82.

${ }^{66}$ Ibidem, p. 72.

${ }^{67}$ LÉRY, Jean de. op. cit., 1574, p. 131-2, 135, 143-4. Ele se refere à "l'extreme auarice d'aucuns qui n'apprehendoyent la main de Dieu en ce temps si calamiteux" (p. 132).

${ }^{68}$ As referências bíblicas fundamentais sobre o cerco de Jerusalém pelos babilônios são 2 Reis 23, 31 - 25, 30; 2 Crônicas 36, além das Lamentações atribuídas a Jeremias; mas a tópica toda do
} 
Na Histoire memorable, Jean de Léry não se preocupa apenas em sinalizar o projeto utópico, sugerido por seu relato das dinâmicas organizativas da cidade; preocupa-se também em dar conta das causas do fracasso desse projeto, não apenas em Sancerre, mas no território francês como um todo. Vamos encontrar na Histoire memorable uma clara percepção da fraqueza e da depravação humanas, convicções típicas do calvinismo que os eventos calamitosos associados à saison de la Saint-Barthélemy certamente agudizavam. Como sabemos, a leitura huguenote dos violentos massacres que tiveram início em Paris, no domingo 24 de agosto de 1572, procurou explicá-los a partir de dois vetores fundamentais, a incontornável depravação humana provocada pela Queda (e que a violência católica, feita em nome de Deus, ilustraria de forma bastante marcada) e o controle absoluto de Deus sobre a história, capaz de se servir dos piores atos praticados pelos seres humanos. ${ }^{69}$ Em sua reflexão, Léry aprofunda de forma bastante melancólica esse diagnóstico sombrio; a Queda não teria mostrado seus efeitos apenas no partido católico, refletindo-se em sua prática violenta do cerco à cidade, mas deixou seus vestígios também entre os que, isolados em Sancerre, afirmavam pautar suas vidas pelos códigos reformados. Presente no ser humano mesmo após sua regeneração pela verdade evangélica, o pecado seria força que se precisava levar em conta na feitura de qualquer projeto cívico.

Esse olhar desencantado pode ter impedido que os calvinistas endossassem algumas leituras otimistas quanto à bondade humana, presentes em outras formulações utópicas; mas não podemos concluir, como faz Lestringant, que essa perspectiva, reforçada por tais acontecimentos sombrios, tenha incentivado no calvinismo a postergação das expectativas utópicas exclusivamente para o futuro escatológico. ${ }^{70}$ Sem dúvida, para a teologia calvinista somente a eternidade revelaria os nomes dos eleitos e inauguraria a possibilidade de uma existência sem mal. Mas essa mesma teologia continuava a dar espaço, na história, para a edificação do projeto teológico-político calvinista; um projeto não desprovido de matizes utópico-apocalípticos.

\footnotetext{
cerco depende muito de Deuteronômio 28, 15-68 (texto tradicionalmente considerado profecia do cerco e do exílio como castigos, mas que hoje a crítica bíblica sabe ser posterior ao próprio cerco, que recebe nele uma leitura retrospectiva). Para a dependência de Josefo, ver Guerra dos Judeus, VI, iii, 4 (esta dependência foi assinalada por NAKAM, Géralde (ed.). Au lendemain de la Saint-Barthélemy, guerre civile et famine. L'Histoire mémorable du siège de Sancerre (1573). Paris: Anthropos, 1975, p. 164ss, e por LESTRINGANT, Frank. op. cit., 1996, p. 65).

${ }^{69}$ Ver em especial CROUZET, Denis. op. cit., 1994, p. 39-50.

${ }^{70}$ LESTRINGANT, Frank. op. cit., 1994, p. 28-9.
} 
Para os calvinistas, esse mal interior ao ser humano, para o qual a eternidade traria a superação definitiva, poderia ser minorado no contexto das sociedades humanas através de estrita vigilância; e, graças às impressionantes microrredes de poder operadas pelos consistórios calvinistas, essa dinâmica do controle se espalharia e deixaria sua marca na prática política do Ocidente. ${ }^{71}$

Quanto à pressão exterior, aquela exercida pelos inimigos e que era responsável pela insularidade forçada da utopia, essa seria superada apenas pela busca de um novo lugar para o projeto utópico. Veterano de duas experiências extremas de insularidade, aquela vivida em Sancerre e aquela vivida em anos anteriores, durante as tentativas de implantação da colônia francesa na América do Sul, Léry deixou-nos relatos de ambas. O sonho de edificar uma sociedade nova na chamada França Antártica, iniciado por Nicolas Durand de Villegagnon em novembro de 1555 e ao qual Léry se juntou em 1557, teria sido inviabilizado, de acordo com Léry, pela presença do "inimigo interno", um Villegagnon cripto-papista que traíra seus companheiros calvinistas; o contraponto a esse inimigo interno foi, no âmbito "externo", a atitude amiga dos tupinambás, não obstante os costumes chocantes dos indígenas. Já o sonho de efetuar a criação da nova Jerusalém em solo propriamente francês encontrou, do lado de fora, a dura muralha da realidade de um poder central cada vez menos disposto a se curvar às liberdades municipais, a par da violência quase canibalesca de seus conterrâneos; e, do lado de dentro, o "inimigo interno" representado pela cobiça e pela avareza dos próprios correligionários huguenotes. É extremamente significativo que, tendo perdido as anotações que fizera de sua experiência americana, Léry as tenha reescrito e publicado somente após compor a narrativa sobre Sancerre: os dois relatos encontram-se profundamente inter-relacionados e foi a partir das lentes da vivência do sítio de Sancerre que as experiências de estranhamento, privação e fome narradas na Voyage foram evocadas por Léry. ${ }^{72}$

Embora os textos de Léry permaneçam elusivos quanto à possibilidade de se construir novos ordenamentos sociais fora do continente europeu, parece claro que, sopesadas as dificuldades, a América se mostrava no pensamento do autor como propícia à edificação de uma sociedade nova, desde

\footnotetext{
${ }^{71}$ SCHILLING, Heinz. op. cit., 2008, p. 25-6; REINHARD, Wolfgang. Pressures towards Confessionalization? Prolegomena to a Theory of the Confessional Age. In: DIXON, C. Scott (ed.). The German Reformation: Blackwell Essential Readings. Oxford: Blackwell, 1999, p. 169-92, aqui p. 185-8; BURNETT, Amy N. Basel's Rural Pastors as Mediators of Confessional and Social Discipline. Central European History, vol. 33, ed. 1, 2000, p. 67-85, aqui p. 81-2.

${ }^{72}$ LÉRY, Jean de. op. cit., 1994; ver WHATLEY, Janet. op. cit., 1984, p. 387.
} 
que os elementos humanos empregados nesse projeto estivessem expurgados de membros duvidosos e de apóstatas como Villegagnon. Assim, nem o pessimismo de Léry frente a qualquer possibilidade de conversão dos indígenas, nem sua denúncia das pretensões ibéricas de ocupar a terra sob pretexto missionário, significariam fundamentalmente uma recusa do potencial utópico de que o além-mar estava dotado. ${ }^{73}$

E será, em maior ou menor grau, essa mesma semente utópica que encontraremos nas tentativas colonizadoras empreendidas por calvinistas franceses e ingleses nos territórios americanos, na medida em que era recorrente em seus realizadores a noção de eles próprios não eram outra coisa senão um "novo Israel". ${ }^{74}$ De cidade sitiada, pretendiam tornar-se uma cidade edificada sobre um monte, num espaço livre de inimigos. O ermo, por sua vez e para mencionar outra tópica bastante familiar aos leitores da Bíblia, deveria ser transformado em cidade. Como não considerar utópico - e, nesse contexto, apocalíptico - tal projeto? ${ }^{75}$

Münster e Sancerre - dois cercos, dois ideários diferentes, mas marcados por anseios de natureza utópico-apocalíptica. No primeiro, os relatos do cerco se prestaram, especialmente, a possibilitar a contra-utopia, o desancamento das pretensões utópicas e sua neutralização. Contrariamente ao que dirão os que, no futuro, se considerarão herdeiros dos "anabatistas", o projeto de Münster era teológico-político e incluía uma reconstrução violenta da "república cristã" em termos de sociedade homogênea. Tratava-se do reinado utópico de Beukelzs, precursor do reino de Cristo na terra; mas desde já um reino destinado unicamente aos santos e que, apesar de anular a separação, consagrada na cristandade ocidental, entre as esferas secular e religiosa, reproduzia aspectos importantes do velho modus de existência proposto pela noção de respublica christiana. No segundo, as difíceis circunstâncias do cerco obrigaram os próprios assediados (ou pelo menos o próprio Léry) a repensar as condições de sua utopia e as razões de seu fracasso. No calvinismo não

\footnotetext{
${ }_{73}$ Para esse pessimismo, ver LÉRY, Jean de. op. cit., 1994, cap. XVI (especialmente p. 420); LesTRINGANT, Frank. op. cit., 1994, p. 37.

${ }^{74}$ Ver L'Histoire notable de la Floride sitvee es Indes Occidentales, contenant les trois voyages faits en icelle par certains Capitaines E Pilotes François, descrits par le Capitaine Laudonniere, qui y a commandé l'espace d'vn an trois moys: à laquelle a este adiousté vn quatriesme voyage fait par le Capitaine Gourgues. Mise en lumiere par M. Basanier, gentil-homme François Mathematicien. A Paris, Chez Guillaume Auuray, ruë sainct Iean de Beauuais, au Bellerophon couronné. M. D. LXXXVI; MATHER, Cotton. op. cit., 1702; CAÑIZARES-ESGUERRA, Jorge. Puritan Conquistadors. Iberianizing the Atlantic, 1550-1700. Stanford: Stanford University Press, 2006, p. 83-214.

75 Para as tópicas mencionadas, ver Mateus 5, 14; Isaías 40, 3.
} 
havia apenas um projeto teológico-político sereno, passavelmente racional, como se procurou ressaltar posteriormente, mas uma orientação utópico-apocalíptica que, talvez, a recusa fortíssima aos anabatistas e suas práticas apenas tentasse mascarar. Em ambos os casos, a cidade sitiada aparece como o locus onde a utopia surge e, também, onde ela é inviabilizada.

\section{Referências bibliográficas}

\section{Fontes}

BAYLOR, Michael G. The Radical Reformation. Cambridge: Cambridge University Press, 1991 (reimpressão, 1995).

BOUGAIN, Michel. Le jardin spirituel de l'âme dévote. Paris: Alain Lotrian, 1528 (Paris, Bibliothèque nationale de France $[B n F]$ Res. D-26902).

BUSSIERRE, Marie-Théodore Renouard, Vicomte de. Les Anabaptistes: Histoire du Luteranisme, de l'Anabaptisme et du regne de Jean Bockelsohn a Munster. Plancy/Paris: Société de Saint-Victor pour la propagation des bons livres/Sagnier et Bray, Libraires, 1853.

CALVINO, João. A Instituição da Religião Cristã. São Paulo: Editora Unesp, 2009. 2 v.

DETMER, Heinrich (ed.). Hermanni a Kerssenbroch, Anabaptistici Furoris Monasterium Inclitam Westphaliae Metropolim Evertentis Historica Narratio. Münster: Druck und Verlag der Theissing'schen Buchhandlung, 1899-1900. 2 v.

GRESBECK, H. Summarische Ertzelungk und Bericht der Wiederdope und wat sich binnen der Stat Monster in Westphalen zugetragen im Iair MDXXXV. In: CORNELIUS, C. A. (ed.). Berichte der Augenzeugen über das münsterische Wiedertäuferreich, volume II de Geschichtsquellen des Bistums Münster. Münster: Druck und Verlag der Theissing'schen Buchhandlung, 1853.

HOFMANN, Melchior. Das XII Capitel des propheten Danielis ausgelegt. In: KROHN, Barthold. Geschichte der fanatischen und enthusiastischen Wiedertäufer vornehmlich in Niederdeutschland: Melchior Hofmann und die Secte der Hofmannianer. Leipzig: Bernhard Christoph Breitkopf, 1758, p. 84-99

KERSSENBROCK, Hermann von. Narrative of the Anabaptist Madness: The Overthrow of Münster, the Famous Metropolis of Westphalia. Tradução, introdução e notas de Christopher S. Mackay. Leiden/Boston: Brill, 2007. 2 v.

LÉRY, Jean de. Histoire memorable de la ville de Sancerre, contenant les entreprinses, sieges, approches, bateries, assaux et autres efforts des assiegans le tout fidelement recueilli sur le lieu par Jean de Lery. Genève: s.n., 1574, 253 p. Histoire d'un voyage faict en la terre du Bresil [1578]. Texte établi, présenté et annoté par Frank Lestringant. Paris: Le Livre de Poche, 1994.

MATHER, Cotton. Magnalia Christi Americana or, The Ecclesiastical History of New England from its First Planting in the Year 1620 unto the Year of Our Lord, 1698. London: Thomas Parkhurst, 1702.

MONTAIGNE, Michel de. Journal de voyage en Italie par la Suisse et l'Allemagne en 1580 et 1581 (edição M. Rat). Paris: Garnier, 1955. 
NAKAM, Géralde (ed.). Au lendemain de la Saint-Barthélemy, guerre civile et famine. L'Histoire mémorable du siège de Sancerre (1573). Paris: Anthropos, 1975.

\section{Bibliografia Subsidiária}

BACZKO, Bronislaw. Utopia. In: Enciclopédia Einaudi. Lisboa: Imprensa Nacional/ Casa da Moeda, 1985, vol. 5, p. 333-96.

BAKHTIN, Mikhail. A Cultura Popular na Idade Média e no Renascimento: O contexto de François Rabelais. São Paulo/Brasília: Hucitec/Editora da UnB, 4ª edição, 1999.

BERRIEL, Carlos Eduardo Ornelas. Brief notes on Utopia, Dystopia and History. In: VIEIRA, Fátima \& FREITAS, Marinela (ed.). Utopia Matters: Theory, Politics, Literature and the Arts. Porto: Editora UP, 2005, p. 101-5.

BOUWSMA, William J. John Calvin: A sixteenth-century portrait. Oxford: Oxford University Press, 1988.

BRUNNER, Otto. Land and lordship: structures of governance in medieval Austria. Philadelphia: University of Pennsylvania Press, 1992.

BURKE, Peter. Cultura popular na Idade Moderna. Europa, 1500-1800. São Paulo: Companhia das Letras, 2010.

BURNETT, Amy N. Basel's Rural Pastors as Mediators of Confessional and Social Discipline. Central European History, vol. 33, ed. 1, 2000, p. 67-85.

CAÑIZARES-ESGUERRA, Jorge. Puritan Conquistadors. Iberianizing the Atlantic, 15501700. Stanford: Stanford University Press, 2006.

CLARK, Stuart. Pensando com demônios: A ideia de bruxaria no princípio da Europa moderna. São Paulo: Edusp, 2006.

CLASEN, C. P. Anabaptism: A Social History, 1525-1618. Ithaca: Cornell University Press, 1972.

COHN, Norman. The Pursuit of the Millenium. Revolutionary Millenarians and Mystical Anarchists of the Middle Ages. Revised and Expanded Edition. New York: Oxford University Press, 1970.

Cosmos, Chaos, and World to Come: The Ancient Roots of Apocalyptic Faith. New Haven: Yale University Press, 1995

COLLINS, John J. A imaginação apocalíptica: Uma introdução à literatura apocalíptica judaica. São Paulo: Paulus, 2010.

CROUZET, Denis. La nuit de la Saint-Barthélemy. Un rêve perdu de la Renaissance. Paris: Fayard, 1994.

. Les guerriers de Dieu. La violence au temps des troubles de religion, vers 1525-vers 1610. Seyssel: Champ Vallon, 1990. 2 v.

DAVIS, J. C. Utopia y la Sociedad Ideal: Estudio de la literatura utopica inglesa, 1516-1700. México: Fondo de Cultura Económica, 1985.

DAVIS, Natalie Zemon. Culturas do Povo: Sociedade e Cultura no Início da França Moderna. Rio de Janeiro: Paz e Terra, 1990.

DELUMEAU, Jean. História do Medo no Ocidente, 1300-1800. Uma cidade sitiada. São Paulo: Companhia das Letras, 1989. 
FORTUNATI, Vita $\mathcal{E}$ Trousson, Raymond (ed.). Dictionary of Literary Utopias. Paris: Honoré Champion, 2000.

FOSTER, Stephen. The Long Argument: English Puritanism and the Shaping of New England Culture, 1570-1700. Chapel Hill: University of North Carolina Press, 1991.

FRANCO JR., Hilário. Os três dedos de Adão: Ensaios de mitologia medieval. São Paulo: Edusp, 2010.

. A Eva Barbada: Ensaios de mitologia medieval. São Paulo: Edusp, 2010.

A utopia que não está no fim da viagem: a peregrinação medieval. Morus - Utopia e Renascimento, n. 7, 2010, p. 59-82.

FRIESEN, Abraham. Erasmus, the Anabaptists, and the Great Commission. Grand Rapids: Eerdmans, 1998.

GARIN, Eugenio. Ciência e vida civil no Renascimento italiano. São Paulo: Editora da Unesp, 1996.

GINZBURG, Carlo. Olhos de madeira: Nove reflexões sobre a distância. São Paulo: Companhia das Letras, 2001.

GRAY, John. Missa Negra: Religião apocalíptica e o fim das utopias. Rio de Janeiro: Record, 2008.

HALL, David D. Worlds of Wonder, Days of Judgement: Popular Religious Beliefs in Early New England. New York: Knopf, 1989.

HESPANHA, António Manuel. As vésperas do Leviathan. Instituições e poder político. Portugal-Século XVII. Coimbra: Almedina, 1994.

. Para uma teoria da história institucional do Antigo Regime. In: Idem. Poder e Instituições na Europa do Antigo Regime: Colectânea de Textos. Lisboa: Fundação Calouste Gulbenkian, 1984.

HUCHARD, Viviane; BOURGAIN, Pascale. Le Jardin Médieval: un musée imaginaire. Cluny, des textes et des images, un pari. Paris: Presses Universitaires de France, 2002.

JASMIN, Marcelo. Utopia: memória, palavra, conceito. In: STARLING, Heloísa Maria Murgel; RODRIGUES, Henrique Estrada; TELLES, Marcela (orgs.). Utopias agrárias. Belo Horizonte: Editora da UFMG, 2008.

JOUANNA, Arlette; BOUCHER, Jacqueline; BILOGHI, Dominique; LE THIEC, Guy (ed.). Histoire et Dictionnaire des Guerres de Religion. Paris: Editions Robert Laffond, 1998.

LESTRINGANT, Frank. Lumière des martyrs. Essay sur le martyre au siècle des Réformes. Paris: Honoré Champion, 2004.

. Une sainte horreur ou le voyage en Eucharistie, $\mathrm{XVI}^{e}-\mathrm{XVIII}{ }^{e}$ siècle. Paris: Presses Universitaires de France, 1996.

"Léry ou Le rire de l'Indien". In: LÉRY, Jean de. Histoire d'un voyage faict en la terre du Bresil [1578]. Texte établi, présenté et annoté par Frank Lestringant. Paris: Le Livre de Poche, 1994.

MACKAY, Christopher S. General Introduction. In: KERSSENBROCK, Hermann von., Narrative of the Anabaptist Madness: The Overthrow of Münster, the Famous Metropolis of Westphalia. Tradução, introdução e notas de Christopher S. MACKAY. Leiden/Boston: Brill, 2007. 2 v. 
MANUEL, Frank E. \& MANUEL, Fritzie P. El pensamiento utópico en el mundo occidental. Madrid: Taurus, $1984.3 \mathrm{v}$.

MUMFORD, Lewis. The Story of Utopias. New York: Boni and Liveright, 1922.

NEVOLA, Fabrizio. Tales of the City: Outsiders' Descriptions of Cities in the Early Modern Period. Edição especial de Città e Storia VII, 1 (2012). Roma: s.n., 2012.

OESTREICH, Gerhard. Problemas estruturais do absolutismo europeu. In: HespaNHA, António Manuel (org.). Poder e Instituições na Europa do Antigo Regime: Colectânea de Textos. Lisboa: Fundação Calouste Gulbenkian, 1984.

PRODI, Paolo. Uma história da justiça: Do pluralismo dos foros ao dualismo moderno entre consciência e direito. São Paulo: Martins Fontes, 2005.

REINHARD, Wolfgang. Pressures towards Confessionalization? Prolegomena to a Theory of the Confessional Age. In: DIXON, C. Scott (ed.). The German Reformation: Blackwell Essential Readings. Oxford: Blackwell, 1999.

RODRIGUES, Rui Luis. Entre o dito e o maldito: humanismo erasmiano, ortodoxia e heresia nos processos de confessionalização do Ocidente (1530-1685). Tese de doutorado, Faculdade de Filosofia, Letras e Ciências Humanas, Universidade de São Paulo, São Paulo, 2012.

RUYER, Raymond. L'Utopie et les utopies. Paris: Presses Universitaires de France, 1950.

SARTORELLI, Elaine Cristine. Estratégias de construção e de legitimação do ethos na causa veritatis: Miguel Servet e as polêmicas religiosas do século XVI. Tese de doutorado em Letras Clássicas, Faculdade de Filosofia, Letras e Ciências Humanas, Universidade de São Paulo, São Paulo, 2005.

SCHILLING, Heinz. Early modern european civilization and its political and cultural dynamism. The Menahem Stern Jerusalem Lectures. Lebanon: University Press of New England, 2008.

TROUSSON, Raymond. Utopia e utopismo. Morus - Utopia e Renascimento, n. 2, 2005, p. 123-36.

VIELHAUER, Philipp. História da Literatura Cristã Primitiva: Introdução ao Novo Testamento, aos Apócrifos e aos Pais Apostólicos. Santo André: Academia Cristã, 2005.

WHATLEY, Janet. Food and the Limits of Civility: The Testimony of Jean de Léry. The Sixteenth Century Journal, vol. 15, n. 4, 1984, p. 387-400.

WILLIAMS, George H. La Reforma Radical. México: Fondo de Cultura Económica, 1983 (edição original de 1962); . (org.). Spiritual and Anabaptist Writers. Londres: Westminster Press, 1957.

Recebido: 24/06/2016 - Aprovado: 25/11/2016 